Short communication

\title{
INTERFACIAL REACTIONS BETWEEN SILICON BASE CERAMICS AND METALS
}

\author{
Masaaki NAKA \\ Welding Research Institute, Osaka University \\ Mihogaoka 11-1, Ibaraki, Osaka 567, Japan
}

\section{INTRODUCTION}

$\mathrm{SiC}$ is a candidate material for high temperature components. Joining $\mathrm{SiC}$ to metals expands the engineering application, and an understanding of the phase reactions at $\mathrm{SiC} /$ metal interfaces is required. The formation of compounds of $\mathrm{Ti}_{3} \mathrm{SiC}_{2}, \mathrm{Ti}_{5} \mathrm{Si}_{3} \mathrm{C}_{x}$ and $\mathrm{TiC}$ between $\mathrm{SiC}$ and $\mathrm{Ti}$ have been reported [1-2], though details of the process of interfacial reaction are still unclear. Even less reports exist on the other $\mathrm{SiC} / \mathrm{Cr}$ [2] and $\mathrm{SiC} / \mathrm{Nb}$ systems $[3,4]$. Furthermore, information on reaction kinetics such as growth rates and activation energies of growth for reaction phases is necessary to control the $\mathrm{SiC} /$ metal interfacial structure. The present work aims to investigate the interfacial structure, reaction phases and diffusion path between $\mathrm{SiC}$ and metals $\mathrm{Ti}, \mathrm{Cr}$, $\mathrm{Nb}$ and $\mathrm{Ta}$ as well as growth kinetics of reaction phases.

\section{REACTION PHASES AND DIFFUSIONS}

\section{$2.1 \quad \mathrm{SiC} / \mathrm{Ti}$ Couple}

Upon bonding at $1673 \mathrm{~K}, \mathrm{TiC}$ granular phase adjacent to $\mathrm{Ti}$ and $\mathrm{Ti}_{5} \mathrm{Si}_{3} \mathrm{C}_{x}$ containing fine $\mathrm{TiC}$ duplex phase zone next to $\mathrm{SiC}$ are formed during the bonding time of $0.3 \mathrm{ks} . \quad \mathrm{A} \mathrm{Ti}_{5} \mathrm{Si}_{3} \mathrm{C}_{x}$ single phase zone with a hexagonal Nowotny-tye phase appears next to $\mathrm{SiC}$ for the bonding time of $0.9 \mathrm{ks}$. The additional $\mathrm{Ti}_{3} \mathrm{SiC}_{2}$ (T)phase appears between $\mathrm{Ti}_{5} \mathrm{Si}_{3} \mathrm{C}_{x}$ and $\mathrm{SiC}$ after the bonding time of $3.6 \mathrm{ks}$. In $\mathrm{SiC} / \mathrm{Ti} / \mathrm{SiC}$ joint formed at $1673 \mathrm{~K}$ for $7.2 \mathrm{ks}$, unreacted titanium is still observed at the central part of the couple at this time. The sequence of phases observed at $1673 \mathrm{~K}$ for the bonding condition shows the complete diffusion path between $\mathrm{SiC}$ and $\mathrm{Ti}$ as follows; $\mathrm{SiC} / \mathrm{Ti}_{3} \mathrm{SiC}_{2} / \mathrm{Ti}_{5} \mathrm{Si}_{3} \mathrm{C}_{x} / \mathrm{Ti}_{5} \mathrm{Si}_{3} \mathrm{C}_{x}+\mathrm{TiC} / \mathrm{TiC}+\mathrm{Ti} / \beta-\mathrm{Ti}$.

As discussed later this diffusion path between $\mathrm{SiC}$ and $\mathrm{Ti}$ at $1673 \mathrm{~K}$ is explained on the tie line connecting $\mathrm{SiC}$ and $\mathrm{Ti}$ in $\mathrm{Ti}-\mathrm{Si}-\mathrm{C}$ ternary diagram, which is presumed from the diagram at $1373 \mathrm{~K}$. The sintering additive may affect the diffusion path. Since $\mathrm{Ti}_{3} \mathrm{SiC}_{2}$ and $\mathrm{Ti}_{5} \mathrm{Si}_{3} \mathrm{C}_{x}$ phases have to appear on the diffusion path, the phase reactions and diffusion at the interface of $\mathrm{SiC}_{1} \mathrm{Ti}_{5} \mathrm{Si}_{3} \mathrm{C}_{x}$ containing $\mathrm{TiC}$ precipitate adjacent to $\mathrm{SiC}$ in $\mathrm{SiC} / \mathrm{Ti}$ couple are still on the way to the diffusion path [1].

\section{$2.2 \mathrm{SiC} / \mathrm{Cr}$ Couple}

Received May 1, 1996
The results on the $\mathrm{SiC} / \mathrm{Cr}$ couple reported by Kurokawa [2] revealed the diffusion path only partially. In the present experiments, $\mathrm{Cr}_{23} \mathrm{C}_{6}$ and $\mathrm{Cr}_{7} \mathrm{C}_{3}$ next to $\mathrm{Cr}$ and $\mathrm{Cr}_{5} \mathrm{Si}_{3} \mathrm{C}_{x}+\mathrm{Cr}_{3} \mathrm{SiC}_{x}$ next to $\mathrm{SiC}$ appear at $1673 \mathrm{~K}$ for the bonding time of $0.3 \mathrm{ks}$. The reaction zones grow with increasing the bonding time to $1.8 \mathrm{ks}$. The complete path between $\mathrm{SiC}$ and $\mathrm{Cr}$ is established at this bonding time at $1673 \mathrm{~K}$ as follows, $\mathrm{SiC} / \mathrm{Cr}_{5} \mathrm{Si}_{3} \mathrm{C}_{x} / \mathrm{Cr}_{3} \mathrm{SiC}_{x} / \mathrm{Cr}_{7} \mathrm{C}_{3} / \mathrm{Cr}_{23} \mathrm{C}_{6} / \mathrm{Cr}$ which is also predicted on $\mathrm{Cr}-\mathrm{Si}-\mathrm{C}$ phase diagram. The chromium at the central is consumed for the bonding time of $3.6 \mathrm{ks}$, and the structure of the joining layer moves to the equilibrium with increasing a joining time. The joining structure becomes $\mathrm{Cr}_{3} \mathrm{C}_{2}$ and $\mathrm{Cr}_{5} \mathrm{Si}_{2} \mathrm{C}_{x}$ zones between $\mathrm{SiC}$, which are consistent with the $\mathrm{Cr}-\mathrm{Si}-\mathrm{C}$ phase diagram.

\section{3 $\mathrm{SiC} / \mathrm{Nb}$ Couple}

In the $\mathrm{SiC} / \mathrm{Nb}$ couple at $1790 \mathrm{~K}$ and for the bonding time of $36 \mathrm{ks}, \mathrm{Nb}_{2} \mathrm{C}$ zone appears next to $\mathrm{Nb}$, and $\mathrm{Nb}_{5} \mathrm{Si}_{3} \mathrm{C}_{x}$ zone containing grains of $\mathrm{NbC}$ is formed next to $\mathrm{SiC}$. X-ray diffraction experiments after mechanically polishing show a thin $\mathrm{NbC}$ layer at the interface between $\mathrm{SiC}$ and $\mathrm{Nb}_{5} \mathrm{Si}_{3} \mathrm{C}_{x}$. The complete diffusion path between $\mathrm{SiC}$ and $\mathrm{Nb}$ is established at this bonding time as $\mathrm{SiC} / \mathrm{NbC} / \mathrm{Nb}_{5} \mathrm{Si}_{3} \mathrm{C}_{x} / \mathrm{NbC}+\mathrm{Nb}_{2} \mathrm{C} / \mathrm{Nb}_{2} \mathrm{C} / \mathrm{Nb}$. This diffusion path was also reported in $\mathrm{Nb} / \mathrm{SiC}$ thin film produced by sputtering [3]. After consuming $\mathrm{Nb}, \mathrm{NbC}$ becomes the layer zone with increasing the bonding time, and finally the layer structures of $\mathrm{NbC}$ and $\mathrm{NbSi}_{2}$ are formed at the bonding temperature of $1790 \mathrm{~K}$.

\section{$2.4 \mathrm{SiC} / \mathrm{Ta}$ Couple}

The reaction zone of $\mathrm{SiC} / \mathrm{Ta}$ joint boned at $1773 \mathrm{~K}$ for $7.2 \mathrm{ks}$ consists of $\mathrm{Ta}_{2} \mathrm{C}$ next to $\mathrm{Ta}$, and $\mathrm{Ta}_{5} \mathrm{Si}_{2} \mathrm{C}_{x}$ next to $\mathrm{SiC}$. At the joining time of $57.6 \mathrm{ks}$ at $1773 \mathrm{~K}$ the reaction zone consists of layered $\mathrm{Ta}_{5} \mathrm{Si}_{3} \mathrm{C}_{x}+\mathrm{TaC}+$ $\mathrm{TaSi}_{2}+\mathrm{SiC}$. Using the Ta-Si-C ternary phase diagram a diffusion $\mathrm{SiC} / \mathrm{TaC} / \mathrm{Ta}_{5} \mathrm{Si}_{3} \mathrm{C}_{x} / \mathrm{Ta}_{2} \mathrm{C} / \mathrm{Ta}$ is concluded.

\section{REACTION MECHANISM}

All diffusion paths between $\mathrm{SiC}$ and the metals $\mathrm{Ti}, \mathrm{Cr}$, $\mathrm{Nb}$, Ta are described along tielines coupling $\mathrm{SiC}$ and these metals via intermediate compounds on the 

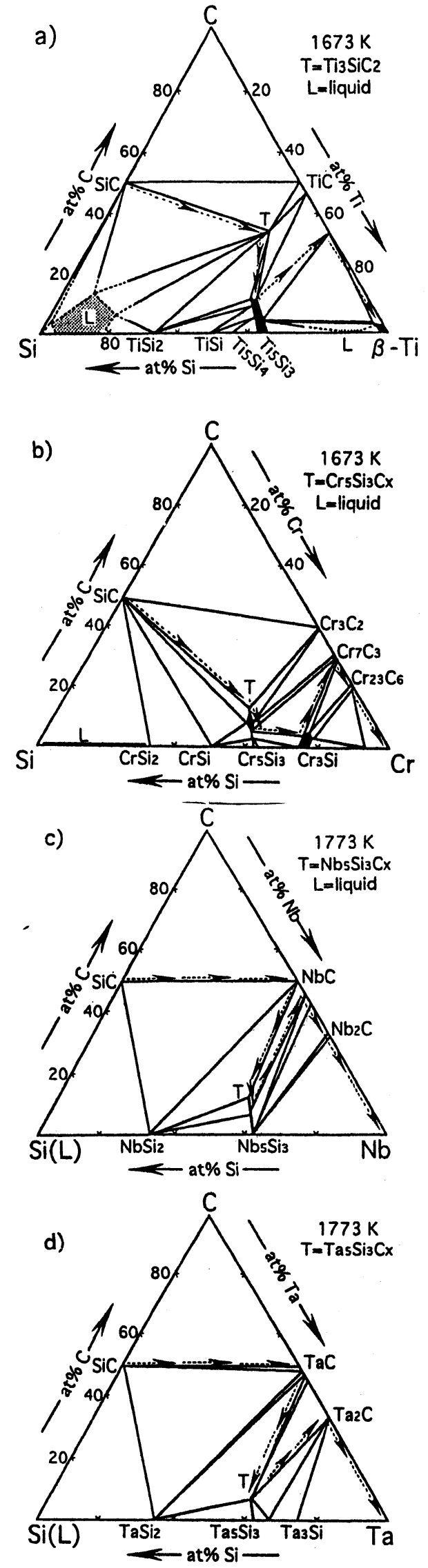

Fig. 1. Diffusion paths between $\mathrm{SiC}$ and metals described on M-Si-C ternary phase diagrams. corresponding M-Si-C ternary phase diagrams (Fig. 1).

The growth rate of reaction zones between $\mathrm{SiC}$ and metal have to be analyzed separately for each compound or zones formed. However, the growth rate of the reaction zone between $\mathrm{SiC}$ and metals was repeatedly treated as a single zone [1-4]. Thus, the present results for the growth rate of $\mathrm{SiC} /$ metal reaction zones are also analyzed as single phase zone as,

$$
\begin{gathered}
x^{2}=k t, \\
k=k_{\mathrm{o}} \cdot \exp \cdot(-Q / R T),
\end{gathered}
$$

where $k_{\mathrm{O}}$ and $Q$ are a rate constant and activation energy for growth of reaction zone. The thickness for reaction zone is expressed in a term of $t^{1 / 2}$. From slopes of plotting $k$ against $1 / T$, activation energies for growth of the reaction zone are obtained. The growth rate for the reaction zone increases in the sequence of $\mathrm{SiC} / \mathrm{Ta}$, $\mathrm{SiC} / \mathrm{Nb}, \mathrm{SiC} / \mathrm{Cr}$ and $\mathrm{SiC} / \mathrm{Ti}$ system.

The $Q$ and $k_{\mathrm{o}}$ in the growth of reaction zone for $\mathrm{SiC} / \mathrm{Ti}$ system are in agreement with results in references [1,2]. Although the $Q$ for $\mathrm{SiC} / \mathrm{Cr}$ system is the same order as that of the $\mathrm{SiC} / \mathrm{Ti}$ system, the growth rate for $\mathrm{SiC} / \mathrm{Cr}$ is lower than that of $\mathrm{SiC} / \mathrm{Ti}$ system. The growth rates of $\mathrm{SiC} / \mathrm{Nb}$ and $\mathrm{SiC} / \mathrm{Ta}$ system are two or three order lower than that of $\mathrm{SiC} / \mathrm{Ti}$ and $\mathrm{SiC} / \mathrm{Cr}$ systems. It means that the reactivities of $\mathrm{Nb}$ and $\mathrm{Ta}$ against $\mathrm{SiC}$ are quite lower than that of $\mathrm{Ti}$ and $\mathrm{Cr}$.

\section{CONCLUSIONS}

Microstructure and reaction phase formed during bonding in vacuum between $\mathrm{SiC}$ and the metals $\mathrm{Ti}, \mathrm{Cr}$, $\mathrm{Nb}$ and $\mathrm{Ta}$ ) were investigated. The complete diffusion path were established after certain bonding time at the bonding temperatures selected. All compounds produced along the tielines connecting $\mathrm{SiC}$ and each of these metals in the corresponding ternary $\mathrm{M}$-Si-C phase diagrams were observed.

The growth rates of the interfacial reaction zones decreased in the sequence of $\mathrm{SiC} / \mathrm{Ti}, \mathrm{SiC} / \mathrm{Cr}, \mathrm{SiC} / \mathrm{Nb}$ and $\mathrm{SiC} / \mathrm{Ta}$. Thus, the reactivity of metals versus $\mathrm{SiC}$ decreased in the order of $\mathrm{Ti}, \mathrm{Cr}, \mathrm{Nb}$ and $\mathrm{Ta}$.

\section{REFERENCES}

1. P. Matineau, R. Pailler, M. Lahaye and R. Naslaim, J. Mater. Sci., 19 (1984) 2479.

2. K. Kurokawa and R. Nagasaki, Proc. Int. Symp. \& Exhib. Sci. \& Technol. of Sintering, Tokyo (1987) 1397.

3. A. Joshi, H. S. Hu, L. Jesion, J. J. Stephans and J. Wadworth, Met. Trans., A 21 (1990) 2829.

4. M. Naka, T. Saito and I. Okamoto, J. Mater. Sci., 26 (1991) 1983. 